\title{
Why Nabors Industries (NBR) Acquired Tesco Corporation (TESO) in an All-Stock Transaction: A Case Study
}

\section{Jameel Mohammed Ahmed and Shanavas Moosafintavida*}

Azteca University, Mexico, North America

*Corresponding author: dr.shanavas@univ-azteca.com

Received: 14 Aug., $2020 \quad$ Revised: 09 Nov., 2020

Accepted: 23 Nov., 2020

\begin{abstract}
This article examines why Nabors Industries (NBR) acquired OFS (Oilfield equipment and services) industry peer Tesco (TESO). The study draws on a dataset from analysts, corporate advisers,and other sources, regarding the acquisition of Tesco by Nabors. The case study illuminates several dimensions of the Tesco \& Nabors international experience before and after acquisitions and why analyst is calling the transaction a win for both buyer and seller? Is the deal also takes out a competitor in the top-drive market? Nabors Industries' $\$ 216$ million acquisition of Tesco Corp is still believed as a valuable deal at the oilfield services industry.
\end{abstract}

Keywords: Acquisitions, Analyst, International experience

Nabors Industries Ltd. (NYSE: NBR) acquired all the issued and outstanding common shares of Tesco Corporation (NASDAQ: TESO), with each outstanding share of common stock of Tesco being exchanged for 0.68 common shares of Nabors. This deal created a leading rig equipment and drilling automation provider by merging Canrig, Nabors rig equipment subsidiary, with Tesco's rig equipment manufacturing, rental, and after market service business. Additionally, Tesco operated as a tubular services business in numerous key regions globally, which is believed to be benefited Nabors Drilling Solutions' operation. Nabors and Tesco contributed to a prolonged heritage of innovation, with inventions that have substantially boosted the safety and effectiveness of drilling operations over the past decade. As Nabors and Tesco implement new levels of drilling automation and analytics, this combination of Tesco and Nabors' remarkable ability and technologies reinforced their capability to increase speed and scale implementation whilst progressing to innovate. 


\section{Transaction Highlights}

Nabors accelerates the automation and integration of pipeline services on drilling rigs and creates instant global capacity for Nabors drilling solutions [1].

Combine a complementary portfolio of products, services, and technologies to strengthen Nabors' position as a global leader in high performance drilling equipment and software.

$\square$ Strengthening the economic position of Nabors through significant commercial and operational professional synergy, experience in Tesco management, human resources, and technology in the operation of Nabors [1].

\section{About Nabors Industries (NBR) \& Tesco Corporation}

Nabors Industries Ltd. owns and operates a fleet of onshore drilling rigs. The company is a supplier of offshore drilling rigs in the United States and many international markets. The company operates in the drilling and drilling industry in four segments: drilling in the United States, drilling in Canada and international drilling and drilling services. The company offers well placement services, drilling software and demonstration equipment, drilling equipment and various technologies for the oil and gas market [2]. The company's rig drilling and installation business includes operations of onshore and onshore rigs and other rig services, including equipment manufacturing, instrumentation, and optimization software. The company offers systems and services for directional drilling and Measurement and Drilling (MWD) operations. The company also provides drilling equipment and technology, as well as well construction services [2]. Nabors has the world's largest land-based drilling fleet, with nearly 400 platforms in more than 20 countries [3].

Tesco Corporation was a world leader in the creation, manufacture, and service of technology solutions for the energy industry. The company was focused on bringing cost-effective technology to the oil and gas industry. Known worldwide as "the best way to dig the bottom" for customers, Tesco was at the forefront of research, development and commercialization of innovative products and services that reduce drilling costs and improve safety and efficiency [4].

The company's two main divisions were the Top Drive Division and its supply of tubular services. Tesco's Top Drive division used to sell and leasemost of the top drives used for drilling. The company's tubular services division provides tools and services for installing pipes and cores in new wells. These include tongs, torque monitoring services, contact testing services and hydropower plants. Tesco's largest markets include the United States, Russia, South America, and Canada [5].

\section{Acquisition Deal: Why Nabors Planned to Acuire Tesco}

The oil services and drilling industry is the worst victim of the oil crisis, with fewer mergers and acquisitions since 2014. During the recession, energy companies focused on various measures to integrate balance sheets and reduce costs. However, as crude prices partially recovered from the recession associated with the recession, energy companies entered several strategic transactions to increase their capacity. Mergers and acquisitions in the oilfield services industry are also increasing as the market stabilizes with fluctuating dynamics in the oil and gas sectors. Combined with limited organic growth, low volumes, 
and low margins, drilling and oilfield services have strengthened companies [6].

Companies are focusing on accelerating mergers and acquisitions that complement their existing portfolios and help expand their capabilities and capabilities. Some M\&A agreements have been signed or completed in recent months. These include the merger of Baker Hughes BHGE and General Electric, the merger of Haliburton Company HAL with Summit ESP LLC, and the merger of Tricon Well Services Limited and Canyon Services Group, Inc. The owners of the world's largest fleet of onshore drilling rigs, and Tesco, known for its technology-based solutions, want to further strengthen Nabors' position as a provider of the latest drilling news, equipment, and services [6].

The acquisition included a total share transaction of \$ 215 million, with all the issued and outstanding shares of Tesco purchased by Nabors in exchange for the previous 0.68 common shares. Under this deal, Tesco's price is $\$ 4.62$ per share, reflecting a 19\% premium over Tesco's closing price of $\$ 3.90$ on August 11, 2017. The value of the transaction is a bonus of $30 \%$ of the total business value based on Tesco's total cash balance. ... June 30, 2017. Tesco shareholders own 10\% of Nabors after the closing of the transaction, which is due in the fourth quarter of 2017, based on necessary permits and satisfactory conditions. However, if the contract does not expire on February 14, 2018, Tesco will be required to pay Nabors a termination fee of $\$ 8$ million [6].

The consolidation was expected to reach \$20 million in the first year. Once the consolidation is fully implemented, Nabors management was expected to raise \$30 million to \$35 million. The rationalization of the system saves capital and the planned ramp up of housing operations could also lead to harmony. The merger was expected to close in the fourth quarter of 2017. The transaction required formal approval. Specifically, Nabors Industries acquired a 2.2\% stake in US Oil Equipment \& Services ETF (IEZ), which was decrease $23 \%$ compared to the previous year [7].

\section{Nabors-Tesco Blend a Rare Win-Win in the Uniting Oil Pitch}

Nabors Industries \$216 million acquisition of Tesco corporation may not be a big deal, but it is important as the oilfield services industry continues to integrate. Analysts described the transaction as beneficial for both buyer and seller. According to Seaport Global Securities, Tesco's tubing business will accelerate the growth of Nabors' drilling solutions business, which will help deliver a more integrated offering and boost environmental sales when its numbers are calculated on the platform per day [8]. The deal also eliminates competitors in the top drive market, SGS said. It also said Nabors could accelerate its earnings targets by issuing shares to acquire Tesco, which was out of debt.For Tesco, the company has reached an increasingly important scale in the oil industry: "less is better." The pace of innovation in drilling seams and oilfield technology has also accelerated, and Tesco has made difficult but correct decisions to maintain its global presence and research and development efforts. According to the company, the recession is "a journey that will be increasingly difficult for companies of this size in the long term [8]."

Analysts at Tudor, Pickering, and Holt also liked the deal. This had a lot of strategic implications as it reinforced the vision of using the rig as a rig to add Nabors and provide a higher return on capital. By providing manufacturing services on a global basis as a delivery platform, the two major top drive makers, Tesco and Nabors' unit Canrigg, would further integrate the already relatively integrated product/ service lines that were essential to the directional / horizontal drilling process. It is worth noting that TPH investors had "laser-focused" on Nabors' balance sheet, so it was worth noting that the deal gave 
"minimal" benefit to the company's portfolio structure, proceeded all stock when Tesco was in net cash position [8].

The purchase price is slightly above Tesco’s proposed transaction price of $\$ 4.62$ per share, with a premium of $19 \%$ at the end of the transaction on Friday. According to Seaport, Nabors is rated 5.6 times the 2019 Ebitda target of 12.7 times. After considering at least 30 million estimated synergies, Tesco's implied rating drops to a more reasonable 2019 Ebitda of 4.6 times. It would be interesting to see if these cost savings were completed. Tesco’s \$ 25 million research and development costs and product offerings from both companies are expected to significantly overlap [8].

\section{Strategic Benefits of Nabors Industries}

Tesco is highly respected for its high-quality products and after-sales service. The acquisition of Tesco Corporation benefits mutual customers and shareholder groups. Benefits of Nabors include:

$\checkmark$ The transaction will accelerate the integration of automated pipe services in Nabors's global presence. With Rig Operating System's largest land drilling fleet and automation functions, Nabors is in a unique position to deploy Tesco's Premium Chassis Drive Tools and Automation technology worldwide. This business will also create immediate global reach for Nabors drilling solutions [9].

$\square$ The combination of Nabors and Tesco features will make your product, service, or solution more appropriate for customers. Increased capacity helps companies improve operational efficiencies in next-generation operations, accelerate and develop new, next-generation equipment, and upgrade old parts for a new era of drilling. This elevates Nabors's position as one of the world leaders in the performance drilling equipment and software industry [9].

The transaction also strengthens the financial position of the Nabors through additional cash flows and significant commercial and operational coordination. The first-year investment coherence is expected to reach $\$ 20$ million, with a $\$ 30$ million to $\$ 35$ million investment coherence. The company also expects to save capital through planned construction of facilities and enclosure business [9].

$\square$ Nabors also benefit from Tesco's experienced leadership, highly skilled staff, and advanced technology [9].

$\square$ Nabors' acquisition of Tesco is seen as a “cautious next step" in building the company's technology toolbox and its aftermarket presence. The acquisition of Tesco will accelerate the company's vision of developing ultra-high rigs, enhancing the quality of NBR's premium powertrain offering and adding a case racing tool to its product portfolio [10].

$\square$ Tesco's in-house pipeline service will guarantee its status in Saudi Arabia as Tesco's leading position in the market in the Kingdom. In addition, Nabors should be able to increase the presence of the Tabo service on L48, following the established NBR standard (of which there is truly little at present) [10].

Nabors 'acquisition of Tesco will accelerate Nabors' vision and scale, and an increase in equipment orders could increase the potential for cross-selling with Canrig [10]. 


\section{Tesco Corporation $3^{\text {rd }}$ Quarter 2017 Report Before Acquisation}

$\square$ Estimated $\$ 1.0$ million in transaction payments and $\$ 1.4$ million to restructure payments in the third quarter. 64.6 million in cash and no debt at the end of the third quarter. Reported losses through US GAAP, with EPS \$ (0.28) at a net loss of \$13.0 million and \$ (0.20) at an adjusted net loss of $\$ 9.2$ million. $\$ 3.8$ million fee on adjusted EPS. Adjusted EBITDA loss improved 46\% to $\$ 2.1$ million in third quarter, revenue growing slowly at $1 \%[11]$.

$\square$ Tesco Corporation improved its business, especially in Tubular services, which are benefiting from rising CDS and overseas sales in the third quarter, as well as reducing the cost of expanding US land. Despite declining sales of used record players, there has been a steady improvement in sales and EBITDA. Furthermore, although Hurricane Harvey had a small effect on our financial results (EBITDA at approximately UD \$ 0.2 million), it had a significant direct impact on many of our employees [11].

$\square$ Tesco reported revenues of $\$ 40.4$ million in the third quarter of 2017 , or more than $1 \%, \$ 30.4$ million in the third quarter of 2017, and \$30.4 million, or 33\% more than in 2016 .

$\square$ Cash and cash equivalents decreased \$7.9 million between the second quarter of 2017 and September 30, 2017. \$64.6 million mainly due to operating losses and \$1.0 million. If working capital remains relatively stable at the end of the second quarter, a decline in working capital was expected. \$4 million worth of international payments have been delayed but were expected to be paid in the fourth quarter [11].

$\square$ Inventory resulted in an increase in sales of approximately $\$ 3$ million, primarily to support the expected increase in high-end record sales in the fourth quarter. Free cash flow was approximately $\$ 9.9$ million in cash before revenue of approximately $\$ 1.0$ million in transaction-related payments and $\$ 1.4$ million in restructuring payments [11].

$\square$ Product sales in Q3 2017 include 7 new top drive units sold in Q2 2017 (4 new and 3 used) and 3 new top drive units sold in Q3 2016. This includes. In the third quarter of 2017, a new catwalk took place. At the end of the third quarter, the fleet had 113 top drives, with usage of 18 of $15 \%$ in the second quarter.

US GAAP had an operating loss of 2.2 million to 2.3 million in the second quarter of 2017 , before adjusting to the tubular services segment in the third quarter of 2017 . Operating loss and operating margins were adjusted to 0,7 million and (3) \% after the third quarter, compared to 14.1 million and (20) $\%$ in the second quarter of 2017, respectively. The gradual improvement is mainly due to higher sales of CDs abroad and a favorable combination from the United States. - The acceleration of the ground is done by reducing costs [11].

\section{DISCUSSION}

Given the interdependence of markets for increased goods and services and increased foreign competition, we are living in times of significant change. Therefore, many companies are expanding their geographic reach. Often companies that choose to grow will want to compensate their shareholders to gain additional market share, reach new customers, make financial gains, and so on. Companies that do not grow will fail because of their losses, Consumer and market share, shareholder and share price and more. Nowadays the development in many cases includes mergers and acquisitions (M\&A): In the last few years there 
have been 30,000 M\&A transactions, which is one transaction every 17 minutes [12]. There are several reasons for deciding to participate in M\&A agreements.

Expansion: This is the main reason why visual deficiencies are determined to increase. There are two growth options: internal or organic growth and inorganic growth or external methods. According to the findings of Android, Stafford [13], with the intention of increasing the capital base of internal investment companies such as mergers and acquisitions, is expected to grow well.

$\square$ Synergy: Gaughan [14] argues that the term "synergy" often means physics rather than economics or finance. It refers to the type of reactions when two objects or factors act independently of each other, producing more effects than the sum of two. Simply put, synergy refers to the occurrence of $2+2=5$. In a merger, this means that a business merger may be more profitable than the individual parts of a joint venture. There are two main types of synergy [15]: Operating synergy and Financial synergy.

$\square$ Access to intangible assets: The advent of the age of knowledge since the 1980s has brought great changes in the global and local markets. Knowledge plays an important role as a basis for the development of key organizational resources and organizational capabilities for the transformation of the industry. Today, the value of immature knowledge-based resources in the industry is increasing geometrically. Immovable assets include: Human Capital, Customer Capital, and Structural Capital [16].

$\square$ Other Reasons: Apart from expansion, synergy and access to intangible assets, there are many other reasons why companies are involved in mergers and acquisitions are : Horizontal and vertical integration, Improved management, Tax benefits, Changes in markets, Changes in technology and industry, Cost reduction, Extension of R\&D capacities, and Obtaining a new customer base [14], [16], [17], [18]

\section{CONCLUSION}

In short, the following conclusions can be drawn:

Mergers and acquisitions are understood as a general global trend related to the global restructuring of companies in all sectors. They are the lifeline of a healthy economy and are the primary means by which businesses benefit their owners and investors.

$\square$ From the buyer's point of view, the strategic objectives of M\&A deals are primarily related to decision-making (rather than rapid growth in equity) and real estate assets: human and structural capital. And access to clients' capitalfor additional goals include consistency, currency adjustment, real estate, mismanagement issues, and tax savings. From the seller's point of view, the strategic goals of selling a business include converting shares to cash, maximizing growth, increasing prices, leaving owners, and not having access to capital.

$\square$ Contact regression analysis for four selected factors. The total number of M\&A transactions, the country's GDP, incoming and outgoing FDI - showed a strong relationship. Between the number of M\&A transactions and the total cost of M\&A; gross domestic product; Inbound IDE. Simple linear regression analysis - concluded that $\mathrm{Y}=972.83+7.13 \mathrm{X} 1$ while $\mathrm{X} 1=\mathrm{M} \& \mathrm{~A}$ values and $\mathrm{Y}$ $=592.30+0.70 \mathrm{X} 2$, while X2 $=$ GDP can be used when planning and forecasting. 
A thorough qualitative analysis of integration and acquisition shows that most respondents also recognize the benefits of M\&A transactions. Today, however, they have no plans to buy / sell the business. The paradox is that most people say that if the offer is accepted, they will not consider buying a business. If the offer is accepted, there is no clear position regarding the sale of the business.

\section{REFERENCES}

1. CISION PR WIRE. 2017. Nabors Announces Agreement to Acquire Tesco Corporation in an All-Stock Transaction. [Online] Available at: https://www.prnewswire.com/. [Accessed 1 September 2020].

2. REUTERS. 2020. Nabors Industries Ltd.NBR.N. [ONLINE] Available at: https://www.reuters.com/. [Accessed 1 September 2020].

3. Wikipedia. 2020. Nabors Industries. [Online] Available at: https://en.wikipedia.org/. [Accessed 1 September 2020].

4. Energy, Oil \& Gas. 2020. TESCO Corporation. [Online] Available at: http://www.energy-oil-gas.com/. [Accessed 2 September 2020].

5. SEC Edgar Filing Tracker. 2018. Tesco Corp SEC CIK \#0001022705. [ONLINE] Available at: https:// sec.report/. [Accessed 2 September 2020].

6. Yahoo Finance. 2017. Nabors (NBR) Acquires Tesco for \$215M in an All-Stock Deal. [ONLINE] Available at: https://uk.finance.yahoo.com/. [Accessed 1 September 2020].

7. Market Realist. 2017. Why Nabors Plans to Acquire Tesco. [ONLINE] Available at: https://marketrealist. com/. [Accessed 3 September 2020].

8. FORBES. 2017. Nabors-Tesco Merger A Rare Win-Win in The Consolidating Oil Patch. [ONLINE] Available at: https://www.forbes.com/. [Accessed 2 September 2020].

9. Yahoo Finance. 2017. Corporate News Blog - TESCO Enters into a Stock-for-Stock Combination Agreement with Nabors Industries. [ONLINE] Available at: https://in.finance.yahoo.com/. [Accessed 3 September 2020].

10. OE (Offshore Engineer). 2017. Tesco acquisition 'prudent step' in Nabors strategy. [ONLINE] Available at: https://www.oedigital.com/. [Accessed 2 September 2020].

11. Globenewswire. 2017. Tesco Corporation Reports Third Quarter 2017 Results. [ONLINE] Available at: https://www.globenewswire.com/. [Accessed 1 September 2020].

12. Faulkner, D.O. and Campbell, A. 2003. Oxford Handbook of Strategy, Volume II: Corporate Strategy. Oxford University Press.

13. Andrade, G. and Stafford, E. 2004. Investing the economic role of mergers, Journal of Corporate Finance, 10: $1-36$.

14. Gaughan, P.A. 2007. Mergers, Acquisitions, and Corporate Restructurings. John Wiley \& Sons. 
15. DePamphilis, D. 2003. Acquisitions and Other Restructuring Activities: An Integrated Approach to Process, Tools, Cases, and Solutions. Butterworth-Heinemann.

16. Ghosh, A., Jain, P.C. 2000. Financial leverage changes associated with corporate merger, Journal of Corporate Finance, 6: 377-402.

17. Cassiman, B. and Colombo M.G. 2006. Mergers and Acquisitions: The Innovation Impact. Edward Elgar Publishing.

18. Kreitl, G. and Oberndorfer, W.J. 2004. Motives for acquisitions among engineering consulting firms, Construction Management and Economics, 22: 691-700. 